\title{
Research Design for Testing Archaeological Site 41ME29 State Highway 16 Medina County, Texas
}

Wayne C. Young

Follow this and additional works at: https://scholarworks.sfasu.edu/ita

Part of the American Material Culture Commons, Archaeological Anthropology Commons, Environmental Studies Commons, Other American Studies Commons, Other Arts and Humanities Commons, Other History of Art, Architecture, and Archaeology Commons, and the United States History Commons

Tell us how this article helped you.

This Article is brought to you for free and open access by the Center for Regional Heritage Research at SFA ScholarWorks. It has been accepted for inclusion in Index of Texas Archaeology: Open Access Gray Literature from the Lone Star State by an authorized editor of SFA ScholarWorks. For more information, please contact cdsscholarworks@sfasu.edu. 


\section{Research Design for Testing Archaeological Site 41ME29 State Highway 16 Medina County, Texas}

\section{Licensing Statement}

This is a work produced for the Texas Department of Transportation (TxDOT) by the report producer. TxDOT and the report producer jointly own all rights, title, and interest in and to all intellectual property developed under TXDOT's contract with the report producer. The report may be cited and brief passages from this publication may be reproduced without permission provided that credit is given to both TXDOT and the report producer. Permission to reprint an entire chapter, section, figures or tables must be obtained in advance from either the Supervisor of the Archeological Studies Branch, Environmental Affairs Division, Texas Department of Transportation, 125 East 11th Street, Austin, Texas, 78701 or from the report producer. 

RESEARCH DESIGN FOR TESTING ARCHAEOLOGICAL SITE 41ME2 9
STATE HIGHWAY 16
MEDINA COUNTY, TEXAS

Wayne C. Young

Texas

State Department of Highways and Public Transportation

Highway Design Division

October 1984 
INTRODUCTION

Archaeological Site 41ME29 is located in Medina County along the western bank of San Geronimo Creek at the intersection of a major terrace system and a high ridge line. The site contains a prehistoric burned rock midden which has been largely buried by colluvial deposits from the ridge line. Disturbances appear to be minimal.

Testing of portions of the site within the highway right-of-way is being initiated by the State Department of Highways and Public Transportation (SDHPT) in accordance with Procedures for the Protection of Historic and Cultural Properties (36 CFR, Part 800), procedures prescribed by law and endorsed by the Federal Highway Administration. Objectives of the testing will be to determine the nature of the site, its cultural affiliation, and whether the portions within the highway right-of-way meet the criteria for inclusion within the National Register of Historic Places.

Specifically, the site will be tested to determine the depth of the cultural deposits and the limits of the site within the right-of-way. Cultural context and stratification of artifacts recovered will also be of prime concern. Cultural features will be pursued to the extent that their nature and cultural affiliation can be determined. Artifacts and cultural debris will be recorded in situ where possible. Documentation will consist of field notes, level reports, drawings, profiles, and photographic records. 


\section{PROJECT DESCRIPTION}

The project consists of federally funded improvements to $\mathbf{S H} 16$ in Medina County, involving the widening of the existing two-lane roadway to four lanes. The project begins at Park Road 37 in Medina County and extends 2.37 miles to the Medina County line. The project is in a rural setting and involves expanding the width of the existing right-of-way from 80 to $220 \mathrm{ft}$. In the area of $41 \mathrm{ME} 29$ the highway right-of-way will be widened approximately $100 \mathrm{ft}$. 


\section{SITE DESCRIPTION}

Archaeological Site 41 ME $29 \mathrm{w}$ as recorded by Wayne Young of the SDHPT cultural resources staff in October 1984 as a result of an archaeological survey of the SDHPT project on State Highway 16. The site contains a small burned rock midden located near the boundary of a large terrace on the west bank of San Geronimo Creek. The site is located at the southern edge of the terrace where it intersects a high ridge line and stands about 3 meters above San Geronimo Creek. The size of the site is difficult to determine as colluvial slope wash has buried much of the burned rock midden and adjacent areas of the site; but approximately 1 acre is thought to be the extent of the site area, as evidenced by very scattered burned rock fragments. The site appears to be intact with no obvious signs of disturbances. The area may have been plowed sometime in the past and this is expected to be the only major impact to have damaged the site.

Testing of the site is recommended to determine size, depth, cultural affiliations, and significance. Depth of the deposits could not be determined from the survey, but the soil survey data from the area (Dittmar et al. 1977) sug-, gest the possibility of depths extending to a meter beneath the present ground surface. 


\section{TESTING PROCEDURES}

Archaeological testing will consist of hand-excavated units. Due to the limited size of the new right-of-way, no fewer than three and no more than ten test units are anticipated to be necessary to determine the significance of the portions of the site within the project limits. These units will be excavated in 10 om levels from ground surface to sterile deposits.

Horizontal control will be maintained by utilizing the SDHPT project centerline, a known line of exact legal declination. Vertical control will be maintained in relation to present ground surface of each test unit. Matrix excavated from all test units will be passed through .25 in. mesh hardware cloth, with all recovered artifacts and cultural debris being retained for analysis. Recovered materials will be bagged and labeled according to provenience and will be removed from the site to the SDHPT Archaeology Laboratory for temporary curation. Horizontal placement of units will be based on surface observations. Most units will be placed outside the burned rock midden in an effort to locate activity areas adjacent to the midden. Upon completion of the testing, a report detailing the results will be prepared with appropriate maps, profiles, and photographs. Additional recommendations will be made at that time, as well as determination of eligibility for inclusion within the National Register of Historic Places. 
RESOURCE POTENTIAL

Based on the 1984 survey of Site 41 ME 29 very little is known about the site, aside from the fact that it contains a burned rock midden. Only two flint chips were observed on the surface and no diagnostic artifacts were recovered. The site apparently has potential to contribute to the Central Texas Archaic Study Unit (Brown et al. 1982). The site lies within the Central Texas Archaic Study Unit and the occurence of the burned rock midden would suggest Archaic affiliations. The southern Coastal Texas Archaic Study Unit may also be reflected in the site.

At present, it is uncertain if Site 41 ME 29 would yield information relative to the Late Prehistoric or Historic Study Units. 
REFERENCES CITED

Brown, Theodore M., Kay L. Killen, Helen Simons, and Virginia Wulfkuhle 1982 Resource Protection Planning Process for Texas. Texas Historical Commission. Austin.

Dittmar, Glenn W., Michael L. Deike, and Davie L. Richmond 1977 Soil Survey of Medina County, Texas. United States Department of Agriculture Soil Conservation Service and Texas Agricultural Experiment Station. 